\title{
PENINGKATAN HASIL BELAJAR GEOGRAFI SISWA KELAS XII MATERI PERWILAYAHAN DENGAN MENERAPKAN MODEL GROUP INVESTIGATION
}

\author{
AFIFAH \\ SMA Negeri 64 Jakarta \\ e-mail: afifahsma64jkt@gmail.com
}

\begin{abstract}
ABSTRAK
Penelitian ini bertujuan untuk meningkatkan hasil belajar geografi siswa kelas XII materi perwilayahan dengan menerapkan model Group Investigation (GI). Penelitian dilakukan di SMA Negeri 64 Jakarta pada semester gasal tahun 2021. Subjek penelitian adalah siswa kelas XII MIPA 1 SMA Negeri 64 Jakarta tahun pelajaran 2021-2022 yang terdiri dari 36 siswa. Teknik pengumpulan data dengan menggunakan tes pilihan ganda dengan jumlah soal sebanyak 20 soal, Terjadi peningkatan hasil belajar siswa pada setiap tindakan, mulai dari pra siklus, siklus I dan siklus II. Rata-rata nilai siswa pada pra siklus sebesar 75,6 dengan jumlah siswa yang mendapatkan nilai tuntas sebanyak 2 orang dan nilai tidak tuntas sebanyak 15 orang. Setelah diterapkan model pembelajaran Group Investigation pada siklus I, ada peningkatan nilai dengan rata-rata nilai kelas sebesar 80,7 dengan jumlah siswa yang mendapat nilai tuntas sebanyak 28 siswa dan nilai belum tuntas sebanyak 8 orang. apabila dibandingkan, antara pra siklus dan siklus I ada peningkatan nilai, tetapi siswa yang mendapat nilai tuntas masih kurang dari $80 \%$ sebagaimana KKM klasikalnya, sehingga peneliti melanjutkan penelitian dengan siklus II. Setelah dilaksanakan siklus II, nilai rata-rata siswa 87,1 terlihat adanya peningkatan, dan jumlah siswa yang mendapatkan nilai tuntas sebanyak 34 siswa, tetapi masih ada 2 siswa yang belum tuntas artinya siswa tidak tuntas kurang dari $20 \%$. Kesimpulan dari hasil penelitian ini adalah penerapan model Group Investigation (GI) dapat meningkatkan hasil belajar geografi siswa materi Perwilayahan kelas XII MIPA I SMA Negeri 64 Jakarta tahun pelajaran 20212022 pada semester gasal.
\end{abstract}

Kata Kunci: model pembelajaran Group Investigation, hasil belajar geografi, kata kunci 3. materi perwilayahan

\section{ABSTRACT}

This study aims to improve the geography learning outcomes of class XII students on zoning material by applying the Group Investigation (GI) model. The research was conducted at SMA Negeri 64 Jakarta in the odd semester of 2021. The subjects of the research were students of class XII MIPA 1 SMA Negeri 64 Jakarta in the academic year 2021-2022 which consisted of 36 students. Data collection techniques using multiple choice tests with a total of 20 questions, there was an increase in student learning outcomes in each action, starting from the pre-cycle, cycle I and cycle II. The average value of students in the pre-cycle is 75.6 with the number of students who get a complete score of 2 people and an incomplete score of 15 people. After the implementation of the Group Investigation learning model in the first cycle, there was an increase in grades with an average class score of 80.7 with 28 students getting complete marks and 8 incomplete scores. when compared, between pre-cycle and cycle I there was an increase in grades, but students who got a complete score were still less than $80 \%$ as the classical KKM, so the researchers continued the research with cycle II. After the second cycle was carried out, the average score of 87.1 students showed an increase, and the number of students who got a complete score was 34 students, but there were still 2 students who had not completed, meaning that students did not complete less than $20 \%$. The conclusion from the results of this study is that the application of the Group Investigation (GI) model can improve student learning outcomes of geography for class XII MIPA I at SMA Negeri 64 Jakarta in the 2021-2022 academic year in odd semesters.

Keywords: Group Investigation learning model, geography learning outcomes 


\section{PENDAHULUAN}

Pendidikan sangatlah penting bagi kehidupan manusia. Zaman selalu berkembang, demikian juga pendidikan yang senantiasa mengalami perubahan dan perbaikan terutama model pembelajaran menjadi lebih inovatif untuk tercapainya pendidikan yang bermutu. Dalam mencerdaskan kehidupan bangsa, peningkatan mutu pendidikan merupakan suatu hal yang sangat penting bagi pembangunan berkelanjutan pada segala aspek kehidupan manusia (Maimunah, 2021).

Pendidikan di sekolah tidak terlepas dari kegiatan pembelajaran. Pembelajaran adalah proses interaksi antar peserta didik, antara peserta didik dengan pendidik, dan antar sumber belajar pada suatu lingkungan belajar (Permendikbud, 2014). Dengan demikian, interaksi dalam proses pembelajaran merupakan hal yang sangat penting, bukan hanya interaksi satu arah dari guru kepada siswa, tetapi interaksi dua arah antar siswa dan juga antara siswa dengan guru. Keberhasilan siswa dilihat dari hasil belajarnya, dan dapat dijadikan acuan sebagai keberhasilan dalam proses pembelajaran. Hasil belajar siswa ditetapkan dengan kriteria ketuntasan minimal (KKM). Tolak ukur keberhasilan siswa apabila mendapat nilai minimal KKM. Siswa yang belum memenuhi KKM, harus mengikuti pembelajaran remidi (Permendikbud, 2014). Banyaknya siswa yang mengikuti pembelajaran remidi, merupakan indikator belum berhasilnya proses pembelajaran.

Peran guru dalam proses pembelajaran sangatlah penting, karena guru merupakan komponen terpenting dalam proses pendidikan. Tetapi pada umumnya, guru masih kurang maksimal dalam usahanya menumbuhkan pola pikir siswa dalam memecahkan suatu masalah. Guru masih kurang kreatif dan lebih banyak ceramah, sehingga komunikasi yang terjadi hanya satu arah. Padahal, Guru mengajar belum tentu siswa belajar. Perlu diingat, mengajar dan belajar merupakan dua proses yang berbeda (Said, dkk, 2017). Demikian juga untuk pembelajaran mata pelajaran geografi yang umumnya belum memenuhi harapan. Pada umumnya pembelajaran belum berpusat pada siswa, sehingga siswa kurang termotivasi untuk mengembangkan kemampuan berfikirnya, hal ini dapat mengakibatkan berdampak buruk terhadap hasil belajarnya, yaitu banyak siswa yang nilainya masih di bawah KKM.

Geografi merupakan salah satu mata pelajaran lintas minat di kelas peminatan MIPA. Salah satu materi pelajaran geografi di kelas XII adalah perwilayahan. Materi inipun sangat luas karena menyangkut berbagai wilayah pembangunan di Indonesia. Materi ini diharapkan siswa mampu mengkomunikasikan konsep perwilayahan dalam perencanaan tata ruang wilayah nasional, propinsi, dan kabupaten/kota. Berdasarkan data tahun pelajaran 2020-2021, dengan nilai KKM individu sebesar 75, dan nilai KKM klasikal sebesar $80 \%$. Nilai siswa kelas XII SMA Negeri 64 Jakarta untuk materi perwilayahan masih banyak yang di bawah KKM. Sehingga, siswa harus mengikuti kegiatan remidi untuk mendapatkan nilai ketuntasan. Hal ini harus dicari solusi untuk meningkatkan hasil belajar siswa.

Model Group Investigation (GI) sebagai salah satu model pembelajaran kooperatif yang kompleks, berusaha menekankan partisipasi aktif pada diri siswa untuk mencari sendiri materi pelajaran yang akan dipelajari melalui bahan-bahan yang tersedia secara berkelompok yang beranggotakan $2-6$ orang (Suhartono \& Indramawan, 2021). Jadi model GI melibatkan siswa berperan aktif dalam pembelajaran dari mulai perencanaan sampai membahas suatu permasalahan melalui investigasi secara berkelompok. Siswa yang diberdayakan aktif akan bisa menemukan pengetahuan secara mandiri dan berimbas pada pemahaman yang mendalam terhadap materi pelajaran serta berpengaruh terhadap hasil belajar. GI merupakan pembelajaran yang menekankan peserta didik mengenal masalah, merumuskan masalah, mencari solusi untuk menemukan fakta gna menarik kesimpulan yang akan disajikan dalam laporan baik lisan maupun tulisan (Asrul, dkk, 2014).

Model pembelajaran GI mempunyai beberapa kelebihan diantaranya membuat siswa bisa lebih aktif, bersemangat dan berani mengemukakan pendapat (Kaharudin \& Hajeniati, 2020). Rumusan masalah pada penelitian ini adalah bagaimana peningkatan hasil belajar geografi siswa kelas XII SMA materi Perwilayahan dengan menerapkan model Grop 
Investigation dan bagaimana model Group Investigation bisa meningkatkan hasil belajar geografi siswa kelas XII materi Perwilayahan? Sedangkan tujuan penelitian ini untuk meningkatkan hasil belajar geografi siswa kelas XII SMA materi Perwilayahan.

\section{METODE PENELITIAN}

Penelitian ini menggunakan metode penelitian tindakan kelas. Penelitian ini dilaksanakan di SMA Negeri 64 Jakarta di kelas XII MIPA 1 tahun pelajaran 2021-2022 pada semester ganjil dengan 2 siklus. Siklus I dilaksanakan pada tanggal 2 Agustus dan 9 Agustus 2021, sedangkan siklus II dilaksanakan pada tanggal 23 dan 30 Agustus 2021. Alasan peneliti memilih kelas ini karena dari seluruh siswa kelas XII MIPA, kelas XII MIPA 1 termasuk kelas yang rata-rata nilai terendah untuk nilai ulangan harian pertama mata pelajaran geografi. Melalui model Group Investigation ini, dilakukan dengan 2 siklus, dan masing-masing siklus diakhiri dengan tes tertulis berupa soal pilihan ganda sejumlah 20 soal. Masing-masing soal diberi skor benar sebesar 5, dan skor salah sebesar 0. Cara perhitungan nilainya yaitu jumlah benar dibagi jumlah seluruh skor dikalikan 100, maka akan didapatkan nilai maksimum 100 . Bagi siswa yang mendapatkan nilai minimal 75 sesuai nilai KKM, maka siswa tersebut sudah tuntas.Penelitian dilaksanakan dengan 2 siklus, masing-masing siklus dimulai dari perencanaan, pelaksanaan, pengamatan dan refleksi.

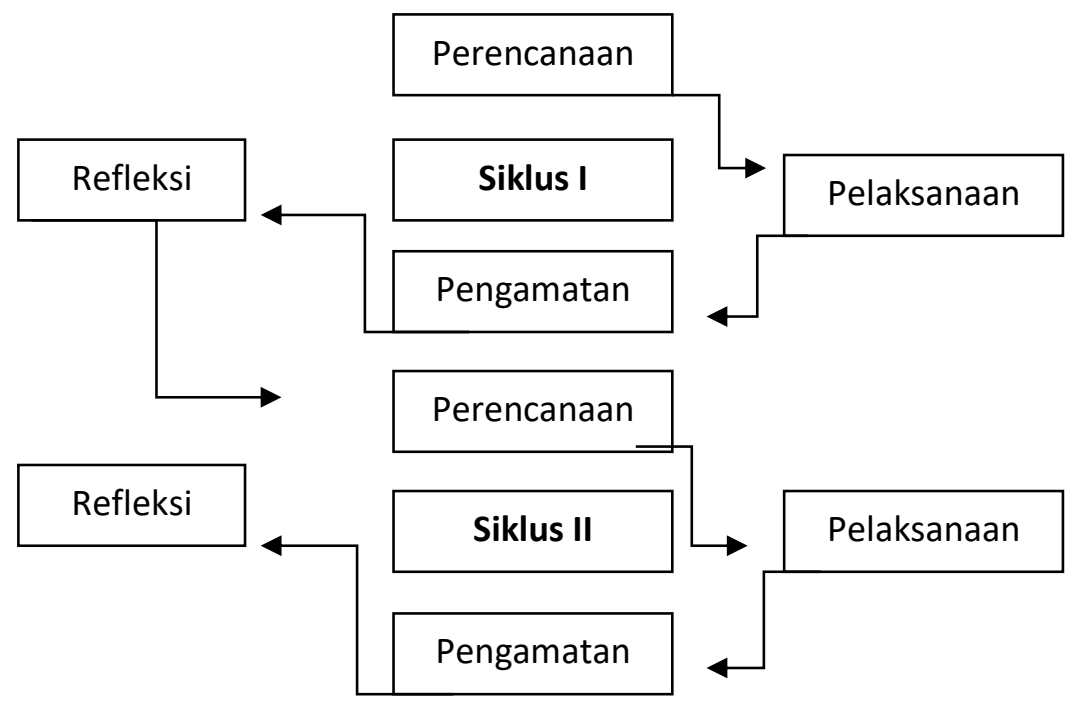

Gambar 1. Siklus Penelitian tindakan Kelas (Arikunto, 2006)

\section{HASIL DAN PEMBAHASAN}

\section{Hasil}

Penelitian tindakan kelas ini dilakukan saat pembelajaran jarak jauh. Jumlah jam pelajaran serta waktu lamanya jam pelajaran dikurangi, sehingga untuk jam geografi kelas XII (3 x 35 menit). Penelitian ini dilakukan dengan 2 siklus. Siklus I dilaksanakan 2 kali pertemuan yaitu tanggal 2 Agustus 2021 dan 9 Agustus 2021. Pada pertemuan pertama siklus I, dijelaskan secara umum materi dan siswa dibagi menjadi 6 kelompok dengan siswa memilih sendiri anggota kelompoknya serta bahasan materinya. Dalam setiap kelompok, siswa berdiskusi dengan anggota kelompoknya, serta siswa mengadakan pembagian tugas kepada masingmasing anggota kelompok untuk mengidentifikasi materi yang ditugaskan. Pada pertemuan kedua, siswa mempresentasikan hasil diskusi masing-masing kelompoknya. Pada pertemuan berikutnya diadakan evaluasi, dengan tes tertulis soal pilihan ganda, jumlah soal 20 soal selama waktu 40 menit. Pada siklus I ini, diperoleh hasil belajar siswa dengan rata-rata nilai kelas sebesar 80,7, meningkat dibanding nilai yang didapatkan saat pra siklus sebesar 75,6. Pada siklus I sebanyak 28 siswa dengan nilai tuntas dan 8 siswa belum tuntas. Secara klasikal lebih 
dari $20 \%$ siswa belom tuntas, artinya siklus I belum berhasil, dan peneliti melanjutkan penelitian pada siklus II.

Siklus II diadakan 23 Agustus 2021 dan 30 Agustus 2021 untuk memperbaiki kegiatan pembelajaran pada siklus I. Pada siklus I penyajian hasil diskusi dilakukan oleh perwakilan, hal ini membuat suasana diskusi masih terbatas, siswa masih belum terlalu aktif. Maka, pada siklus II diskusi lebih detail masing-masing dan semua kelompok beserta sema anggotanya mempresentasikan hasil temuannya. Setelah diadakan tes pada siklus II, didapatkan nilai siswa mengalami peningkatan dibanding nilai pada siklus I. Nilai pada siklus II dengan rata-rata nilai sebesar 87,1 dengan siswa yang nilainya tuntas sebanayk 34 siswa, dan 2 orang siswa yang nilainya tidak tuntas. Hal ini membuktikan siklus II sukses yang berarti terdapat peningkatan hasil belajar geografi siswa dengan model Group Investigation materi Perwilayahan pada kelas XII MIPA I tahun pelajaran 2021-2022.

Peneliti mendapatkan data dari hasil tes siswa dengan bentuk soal pilihan ganda dengan jumlah 20 soal. Berdasarkan hasil tes sebelum siklus, dilanjutkan penilaian setelah siklus I dan diakhiri dengan tes setelah siklus II, diperoleh hasil sebagai berikut

Tabel 1. Nilai Uh Perwilayahan 12 Ipa 1 Tahun 2021-2022 Mata pelajaran geografi sman 64 jakarta

\begin{tabular}{|c|c|c|c|c|c|c|}
\hline \multirow[b]{2}{*}{ NO } & \multirow[b]{2}{*}{ NAMA } & \multicolumn{3}{|c|}{ N I L A I } & \multicolumn{2}{|c|}{ PERUBAHAN NILAI DARI } \\
\hline & & $\begin{array}{c}\text { PRA } \\
\text { SIKLUS } \\
\end{array}$ & SIKLUS I & SIKLUS II & $\begin{array}{l}\text { PRA SIKLUS } \\
\text { KE SIKLUS I }\end{array}$ & $\begin{array}{c}\text { SIKLUS I } \\
\text { KE SIKLUS II }\end{array}$ \\
\hline 1 & ANZ & 45 & 70 & 85 & NAIK & NAIK \\
\hline 2 & AAF & 70 & 85 & 90 & NAIK & NAIK \\
\hline 3 & AAF & 65 & 70 & 85 & NAIK & NAIK \\
\hline 4 & AJN & 85 & 90 & 95 & NAIK & NAIK \\
\hline 5 & AAT & 65 & 90 & 100 & NAIK & NAIK \\
\hline 6 & APS & 85 & 80 & 95 & TURUN & NAIK \\
\hline 7 & $\mathrm{AZA}$ & 65 & 70 & 85 & NAIK & NAIK \\
\hline 8 & $\mathrm{AF}$ & 65 & 55 & 80 & TURUN & NAIK \\
\hline 9 & $\mathrm{BCW}$ & 70 & 85 & 90 & NAIK & NAIK \\
\hline 10 & BAT & 80 & 85 & 90 & NAIK & NAIK \\
\hline 11 & BPA & 85 & 80 & 80 & TURUN & TETAP \\
\hline 12 & CRS & 70 & 80 & 80 & NAIK & TETAP \\
\hline 13 & FMI & 60 & 85 & 80 & NAIK & TURUN \\
\hline 14 & FFL & 70 & 85 & 85 & NAIK & TETAP \\
\hline 15 & GSW & 90 & 85 & 90 & TURUN & NAIK \\
\hline 16 & $\mathrm{HA}$ & 60 & 70 & 85 & NAIK & NAIK \\
\hline 17 & IMS & 65 & 70 & 70 & NAIK & TETAP \\
\hline 18 & MACM & 80 & 85 & 95 & NAIK & NAIK \\
\hline 19 & MK & 80 & 85 & 80 & NAIK & TURUN \\
\hline 20 & MS & 85 & 85 & 95 & TETAP & NAIK \\
\hline 21 & MTK & 80 & 80 & 80 & TETAP & TETAP \\
\hline 22 & MU & 95 & 90 & 95 & TURUN & NAIK \\
\hline 23 & MNM & 70 & 85 & 80 & NAIK & TURUN \\
\hline 24 & MZA & 65 & 70 & 70 & NAIK & TETAP \\
\hline 25 & NAA & 80 & 80 & 90 & TETAP & NAIK \\
\hline 26 & NIF & 80 & 95 & 85 & NAIK & TURUN \\
\hline 27 & NA & 85 & 80 & 85 & TURUN & NAIK \\
\hline 28 & RAF & 85 & 85 & 90 & TETAP & NAIK \\
\hline 29 & $\mathrm{RN}$ & 80 & 80 & 85 & TETAP & NAIK \\
\hline
\end{tabular}




\begin{tabular}{|lllllll}
30 & RNA & 85 & 95 & 85 & NAIK & TURUN \\
31 & RAS & 80 & 65 & 95 & TURUN & NAIK \\
32 & SAP & 85 & 80 & 90 & TURUN & NAIK \\
33 & SAZ & 85 & 85 & 95 & TETAP & NAIK \\
34 & SZA & 85 & 85 & 95 & TETAP & NAIK \\
35 & TAS & 60 & 80 & 90 & NAIK & NAIK \\
36 & WP & 80 & 80 & 90 & TETAP & NAIK \\
\hline \multicolumn{2}{|l|}{ RATA-RATA } & $\mathbf{7 5 , 6}$ & $\mathbf{8 0 , 7}$ & $\mathbf{8 7 , 1}$ & NAIK & NAIK \\
\hline
\end{tabular}

Keterangan: pra siklus : tuntas (21), tidak tuntas (15)

Siklus I : tuntas (28), tidak tuntas (8)

Siklus II : tuntas (34), tidak tuntas (2)

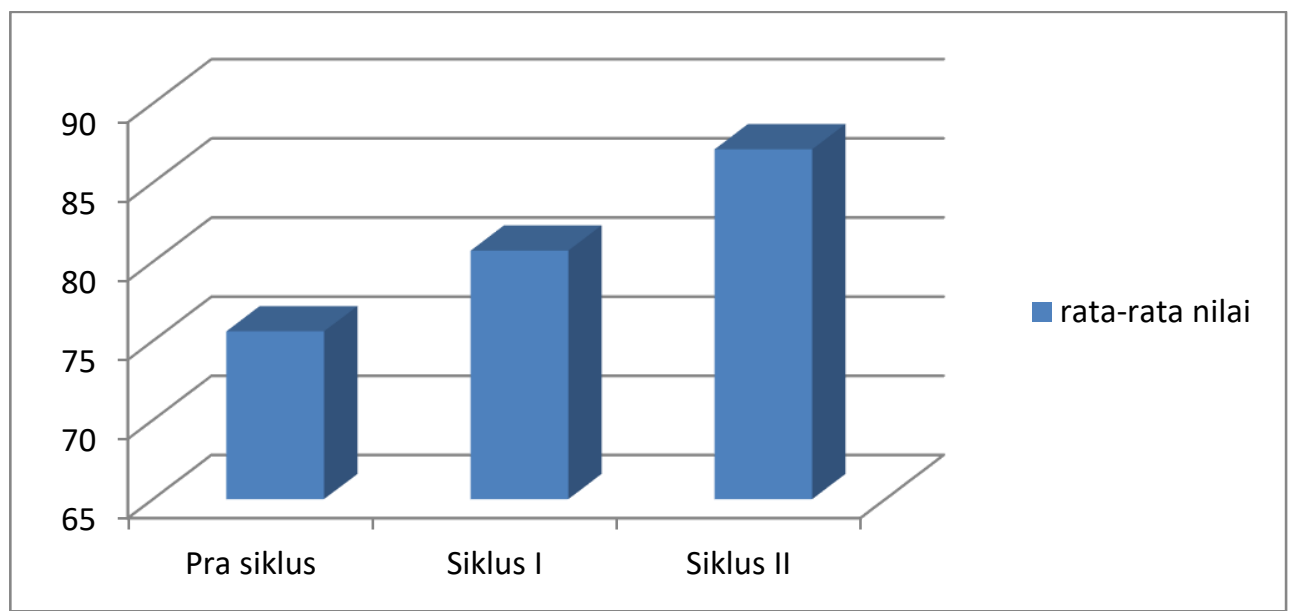

Gambar 1. Peningkatan rata-rata nilai siswa

\section{Pembahasan}

Penelitian tindakan kelas merupakan penelitian yang dilaksanakan di sebuah kelasdi karena terjadinya sebab akibat dari sebuah perlakuan dengan memaparkan seluruh proses dari awal awal perlakuan untuk meningkatkan kualitas pembelajaran (Arikunto, 2015). Penelitian tindakan kelas ini dilaksanakan di kelas XII MIPA I SMA Negeri 64 Jakarta yang berlokasi di Kecamatan Cipayung Jakarta Timur. Penelitian ini bertujuan untuk mengetahui peningkatan hasil belajar geografi dengan model Group Investigation materi Perwilayahan di kelas XII MIPA I SMA Negeri 64 Jakarta pada semester gasal tahun pelajaran 2021-2022. Penelitian ini bermula dari rendahnya rata-rata nilai ulangan harian pertama siswa di kelas ini, yaitu banyaknya siswa yang belum mencapai nilai KKM 75. Hal ini disebabkan karena proses pembelajaran belum melibatkan siswa secara aktif. Dalam pembelajaran, cara guru mengajar masih satu arah dengan ceramah, sedangkan siswa hanya mendengarkan penjelasan guru. Hal ini membuat siswa merasa bosan dan malas untuk menyimak materi pelajaran. Untuk mengatasi rasa bosan pada siswa dalam pembelajaran, diperlukan model Group Investigation yang dapat menarik minat siswa, sehingga siswa terlibat dalam pembelajaran (Hafizar, 2020).

Berdasarkan permasalahan tersebut, peneliti mencoba mencari cara untuk memecahkan permasalahannya. Keberhasilan pengajaran bisa dilihat dari hasil belajar dan proses pembelajarannya, karena hasil belajar merupakan akibat dari proses pembelajaran, dan optimalnya hasil belajar siswa tergantung pada proses belajar siswa serta proses mengajar guru (Sudjana, 2006). Peneliti memulai dengan membuat Rencana Progam Pembelajaran (RPP). Pada RPP, peneliti menerapkan model pembelajaran Group Investigation (GI). Model GI ini dipilih oleh peneliti karena sudah terbukti berhasil meningkatkan hasil belajar peserta didik (Hafizar, 2020). 


\section{KESIMPULAN}

Berdasarkan hasil tes setiap siklus, baik pada siklus I maupun siklus II, maka hasil tes pada siklus I menunjukkan peningkatan dibandingkan dengan sebelum diadakan penelitian atau pra siklus, demikian juga hasil tes pada siklus II menunjukkan peningkatan dibanding hasil tes pada siklus I. Peningkatan tersebut pada perolehan nilai siswa yang mendapatkan nilai di bawah KKM menjadi kurang dari 20\%, dengan demikian nilai hasil belajar siswa baik secara individu maupun secara klasikal sudah memperoleh nilai tuntas. Hal ini disebabkan karena penggunaan model pembelajaran Group Investigation (GI) dapat meningkatan nilai siswa. Jadi, model pembelajaran Group Investigation dapat meningkatkan hasil belajar geografi siswa materi Perwilayahan pada kelas XII MIPA I SMA Negeri 64 Jakarta semester gasal tahun pelajaran 2021-2022.

\section{DAFTAR PUSTAKA}

Arikunto, Suharsimi. (2006). Prosedur Penelitian: Suatu Pendekatan Praktik. Jakarta : PT. Bina Aksara

Arikunto, Suharsimi. Suhardjono. Supardi. (2015). Penelitian Tindakan Kelas (edisi revisi). Jakarta : Bumi Aksara

Asrul, R. Ananda, Rosinta. (2014). Evaluasi Pembelajaran. Cipta pustaka Media

Group Investigation. (2021). Konsep dan Implementasi dalam Pembelajaran. Academia Publication

Hafizar, Hafizar. (2020). Penerapan Model Pembelajaran Tipe Group Investigation untuk Meningkatkan Hasil Belajar Peserta Didik Mata Pelajaran Geografi Materi Pengelolaan Sumber Daya Alam Indonesia. Jurnal Kinerja Kependidikan (JKK)

Kemdikbud. (2016). Permendikbud nomor 23 tahun 2016 tentang standar penilaian Kurikulum 2013. Jakarta

Kaharudin, Andi. Hajeniati, Nining. (2020). Pembelajaran Inovatif \& Variatif Pedoman untuk Penelitian PTK dan Eksperimen. Pustaka Almaida

Maimunah, Maimunah. (2021). "Penerapan Model Pembelajaran Discovery Learning Untuk Meningkatkan Hasil Belajar Geografi Materi Pemanfaatan Peta Pada Siswa Kelas Xii Ips 1 Sma Negeri 1 Syamtalira Bayu Tahun Pelajaran 2019/2020: Penerapan Model Pembelajaran Discovery Learning Untuk Meningkatkan Hasil Belajar Geografi Materi Pemanfaatan Peta Pada Siswa Kelas XII IPS 1 SMA Negeri 1 Syamtalira Bayu Tahun Pelajaran 2019/2020. Jurnal Ragam 2.2

Said, Alamsyah. Budimanjaya, Andi. (2017). Strategi mengajar Multiple intelligences. Mengajar sesuai kerja otak dan gaya belajar siswa. Kencana

Sudjana, Nana. (2006). Penilaian hasil proses belajar mengajar. Remaja Rosdakarya. 